Jp.jok (Jurnal Pendidikan Jasmani, Olahraga dan Kesehatan)

http://ejurnal.budiutomomalang.ac.id/index.php/jpjok

Doi : $\underline{\text { https://doi.org/10.33503/jp.jok.v5i1.1678 }}$

\title{
Technical Readiness Of Physical Education Teachers To Face Online Learning Challenges Due The COVID-19 Pandemic
}

\author{
Wahyu Ragil Kurniawan ${ }^{1)}$, Ipang Setiawan'), Dwi Gansar Santi \\ Wijayanti $^{3)}$, Fatkhur Rozi ${ }^{4)}$, Fani Alfriani ${ }^{5)}$ \\ Program Studi Pedidikan Jasmani Sekolah Dasar \\ Fakultas Ilmu Keolahragaan \\ ${ }^{1,2,3,5}$ Universitas Negeri Semarang, Indonesia \\ ${ }^{4}$ Institut Agama Islam Negeri Salatiga, Indonesia \\ Email: ${ }^{1}$ wahyuragil@mail.unnes.ac.id, ${ }^{2}$ ipang_setiawan@mail.unnes.ac.id, \\ 33wigansarsanti@mail.unnes.ac.id, ${ }^{4}$ fatkhur21@iains alatiga.ac.id. \\ 5 fani.alfriani@students.unnes.ac.id
}

\begin{abstract}
The purpose of this study was to determine the readiness of physical education teachers to face the challenges of how they achieve their learning goals in the midst of COVID-19. The method used in this research is descriptive qualitative, with techniques analyze data by means of questionnaires and interviews. Results of this study indicate that the technical readiness of physical education teachers in elementary schools in Central Java can be interpreted as being ready to face the online leaming system. Conclusion for this study show that, the readiness of physical education teachers in technical matters needs to be a concern. As a suggestion for further research of online quizzes that are easily accessible to students as an alternative to assessing student's cognitive needs to be considered. This research can be a source of information for physical education teachers in preparing to provide physical education learning at elementary school due the COVID-19.
\end{abstract}

Keywords: COVID-19, Physical Education, Technical Readiness

\section{Kesiapan Teknis Guru Pendidikan Jasmani dalam Menghadapi Tantangan Pembelajaran Online pada Masa COVID-19}

ABSTRAK

Tujuan dari penelitian ini adalah untuk mengetahui kesiapan guru penjasorkes dalam menghadapi tantangan bagaimana mencapai tujuan pembelajarannya di tengah pandemi COVID-19. yang digunakan dalam penelitian ini adalah deskriptif kualitatif, dengan total jumlah responden adalah 60 orang dengan latar belakang sebagai guru pendidikan jasmani yang diambil secara acak di seluruh Kabupaten/Kota yang tersebar di Jawa Tengah. Teknik analisis data melalui kuesioner dan wawancara digunakan sebagai alternatif menguatkan jawaban dalam kuesioner. Hasil penelitian ini menunjukkan bahwa kesiapan teknis guru pendidikan jasmani di sekolah dasar di Jawa Tengah dapat diartikan sebagai kesiapan menghadapi sistem pembelajaran online. Kesimpulan penelitian ini menunjukkan bahwa selama pembelajaran online kesiapan guru pendidikan jasmani dalam hal teknis perlu menjadi perhatian. Sebagai saran untuk penelitian selanjutnya kuis online yang mudah diakses siswa sebagai altematif penilaian kognitif siswa perlu diperhatikan. Penelitian ini dapat menjadi sumber informasi bagi guru penjasorkes dalam mempersiapkan diri memberikan pembelajaran penjas orkes dis sekolah dasar akibat COVID-19.

Kata kunci: COVID-19, Pendidikan Jasmani, Kesiapan Teknis,

Info Artikel

Dikirim : 4 Oktober 2021

Diterima : 20 November 2021

Dipublikasikan : 30 November 2021
(C) 2021 IKIP BUDI UTOMOMALANG

P-ISSN 2613-9421

E-ISSN 2654-8003

\footnotetext{
\ Alamat korespondensi: wahyuragil@mail.unnes.ac.id

Universitas Negeri Semarang, Sekaran, Kec. Gn. Pati, Kota Semarang, Jawa Tengah 50229, Indonesia
} 
166 Wahyu Ragil Kurniawan ${ }^{1)}$, Ipang Setiawan ${ }^{2)}$, Dwi Gansar Santi ${ }^{3)}$ Wijayanti $^{3}$, Fatkhur Ro $\dot{z}^{4)}$, Fani Alfriani ${ }^{5}$.Jp.jok (Jurnal Pendidikan. Jasmani, Olahraga dan Kesehatan). 5(1) 165-176

\section{PENDAHULUAN}

COVID-19 telah menjadi tren baru selama beberapa tahun terakhir. Beberapa negara di dunia menerapkan berbagai hal dalam segala aspek kehidupan mulai dari sisi sosial hingga pendidikan untuk mencegah penyebaran COVID-19 (Darling-Hammond \& Hyler, 2020) . Temuan dari beberapa penelitian juga menunjukkan bahwa banyak pendidik dan siswa yang mengandalkan teknologi untuk memastikan pembelajaran online yang berkelanjutan selama pandemi COVID-19 ("Impact of Coronavirus Pandemic on Education," 2020). Berbagai platform pendidikan dimanfaatkan seperti sistem pengelolaan pembelajaran(LMS), YouTube, streaming atau siaran internet, Google Classroom, dan sejenisnya berdasarkan ketersediaannya di negara tertentu. Perguruan tinggi menggunakan Zoom dan Google Meet, sedangkan guru dapat memanfaatkan berbagai situs web, seperti Facebook, WhatsApp, Google Form, untuk tetap berkomunikasi dengan siswanya (Lapada, Miguel, Robledo, \& Alam, 2020).

Salah satu bentuk kegiatan belajar yang dapat dijadikan solusi saat terjadi pandemi Covid - 19 adalah pembelajaran online (Sadikin \& Hamidah, 2020). Salah satu sekolah virtual online publik pertama didirikan pada tahun 1997 dan disebut Florida Virtual School (FLVS). FLVS saat ini menye diakan lebih dari 190 kursus online gratis untuk siswa K - 12, dengan pendaftaran 215.505 siswa, termasuk pendidikan jasmani. Hal tersebut menjadi bukti bahwa kegiatan pembelajaran penjas tetap dapat dilaksanakan walaupun di tengah wabah COVID-19 saat ini, tergantung dari kesiapan para guru (Beard \& Konukman, 2020). Namun demikian pembelajaran virtual merupakan upaya sederhana yang muncul untuk memfasilitasi dan juga alternatif sebagai pendukung tercapainya interaksi edukatif, tetapi belum dapat dikatakan menjadi solusi dalam mencapai tujuan pendidikan di era pandemi COVID-19 (Rahman, Prasetyo, \& Mashuri, 2021)

Pendidikan jarak jauh penting untuk melibatkan siswa dalam proses pengambilan keputusan. Siswa harus didorong untuk menantang, berkolaborasi, dan memecahkan masalah (Bayu, Waluyo, \& Victorian, 2020). Dalam proses ini siswa dan orang tua dapat dihubungi dengan berbagai cara 
seperti surat, email, panggilan telepon, dan video call (Filiz \& Konukman, 2020). Salah satu hasil penelitian menunjukkan bahwa 6 dari 10 guru Taman Kanak-kanak siap menghadapi pembelajaran online, namun 4 guru Taman Kanak - kanak belum siap untuk melakukan pembelajaran online. Penelitian tersebut menegaskan bahwa kesiapan guru sangat penting dalam menghadapi situasi pembelajaran akibat COVID-19 (Ayuni, Marini, Fauziddin, \& Pahrul, 2020).

Hasil penelitian lain mengungkapkan bahwa sarana prasarana yang kurang memadai, penyampaian materi yang belum optimal beban kuota pembelian internet, koneksi internet yang terkadangmenjadi lambat, gaya belajar yang cenderung visual, dan kurangnya fleksibilitas Guru dalam mengontrol aktivitas siswa menjadi alasan kurangnya kesiapan guru dalam menghadapi pembelajaran online (Satrianingrum \& Prasetyo, 2020). Berbagai analis is mengenai proses pembelajaran daring di masa pandemi COVID-19 pada guru juga banyak dilakukan salah satunya menghasilkan pernyataan bahwa pandemi COVID-19 membawa dampak yang sangat besar terhadap proses pembelajaran. Pembelajaran daring yang dilakukan untuk anak usia sekolah dasar dianggap kurang efektif (Putria, Maula, \& Uswatun, 2020).

Kualitas pendidikan adalah salah satu masalah pendidikan yang harus menjadi sorotan penting dalam perbaikan sistem pendidikan, khususnya yang berkenaan dengan kualitas pembelajaran (Panol, Caballes, \& Vasquez, 2021). Dari berbagai kondisi dan potensi yang ada, upaya yang dapat dilakukan untuk peningkatan kualitas tersebut adalah mengembangkan pembelajaran yang berorientasi pada siswa. Pembelajaran yang berorientasi pada siswa dapat dilakukan de ngan membangun sistem pembelajaran yang memungkinkan siswa memiliki kemampuan untuk belajar lebih menarik, interaktif, dan bervariasi (Azra, 2021). Seiring dengan perkembangan teknologi berikut infrastruktur penunjangnya, upaya peningkatan kualitas pembelajaran dapat dilakukan melalui pemanfaatan teknologi tersebut dalam suatu sistem yang dikenal dengan online learning (Hayati, 2020)

Perkembangan teknologi informasi memiliki pengaruh besar terhadap perubahan dalam setiap bidang. Salah satunya ialah perubahan pada bidang 
pendidikan (Moorhouse, 2020). Teknologi dapat dimanfaatkan dalam kegiatan proses belajar mengajar, yang dapat dikatakan merupakan pergantiandari cara konvensional menjadi ke modern. Beberapa penelitian menunjukkan bahwa dengan adanya teknologi memberikan banyak pengaruh positif terhadap pembelajaran (Handarini \& Wulandari, 2020)

Beberapa manfaat dari pembelajaran online atau e-learning diantaranya:

a) Fleksibel. E- learning memberi fleksibilitas dalam memilih waktu dan tempat untuk mengakses perjalanan., b) Belajar Mandiri. E-learning memberi kesempatan bagi pembelajar secara mandiri memegang kendali atas keberhasilan belajar, c) Efisiensi Biaya. E-learning memberi efisiensi biaya bagi administrasi penyelenggara, efisiensi penyediaan sarana dan fasilitas fisik untuk belajar dan efisiensi biaya bagi pembelajar adalah biaya transportasi dan akomodasi (Hayati, 2020).

Berdasarkan beberapa penelitian di atas mengenai kesiapan guru dalam menghadapi pembelajaran situasi COVID-19 maka peneliti tertarik untuk melakukan penelitian terkait kesiapan guru penjas dalam menghadapi pembelajaran online di tingkat sekolah dasar. Penelitian ini dilakukan di Jawa Tengah, Indonesia yang mana merupakan sesuai dengan wilayah kerja tim peneliti. Tujuan dari penelitian ini adalah untuk melihat kesiapan dan faktor apa saja yang menjadi alasan atau pendukung kesiapan guru penjas dalam menghadapi pembelajaran online akibat COVID-19.

\section{METODE}

Jenis penelitian yang digunakan disini adalah deskriptif kuantitatif dimana penelitian ini mempunyai tujuan untuk mendeskripsikan suatu fenomena kesiapan para guru pendidikan jasmani di sekolah dasar dalam menghadapi tantangan pembelajaran online selama COVID-19 . Instrumen dalam penelitian deskriptif kuantitatif ini menggunakan kuesioner (angket). Kuesioner atau angket berisi beberapa pertanyaan tentang persepsi atau pandangan terhadap masalah yang diteliti.

Teknik pengambilan sampel atau subjek penelitian dilakukan dengan cara acak, yaitu tertuju pada guru pendidikan jas mani sekolah dasar baik negeri 
maupun swasta juga madrasah. Sebaran populasi dibatasi di provinsi Jawa Tengah, yang tersebar pada 35 kabupaten/kota. Sampel terdiri dari 60 orang guru pendidikan jasmani sekolah dasar.

Teknik pengumpulan data dalam penelitian ini menggunakan beberapa instrumen diantaranya kuesioner (angket) yang berisi pertanyaan mengenai kesiapan secara teknis para guru kaitannya dengan pembelajaran online untuk pendidikan jasmani. Kuesioner disebarkan bentuk link yang dibagikan melalui whatsapp kepada para subjek penelitian. Selain kuesioner, untuk memastikan hasil data yang di peroleh adalah akurat, maka teknik wawancara diberlakukan. Wawancara tidak dilakukan kepada keseluruhan 60 responden, tetapi hanya dilakukan ketika ada responden yang tidak mengisi lembaran kuesioner

Teknik analisis dalam penelitian ini menggunakan analis is model interaktif, yang terdiri dari; pengumpulan data; reduksi data; tampilan data; dan kesimpulan (Ayuni et al., 2020). Berikut alur teknik analisis yang digunakan dalam penelitian ini:

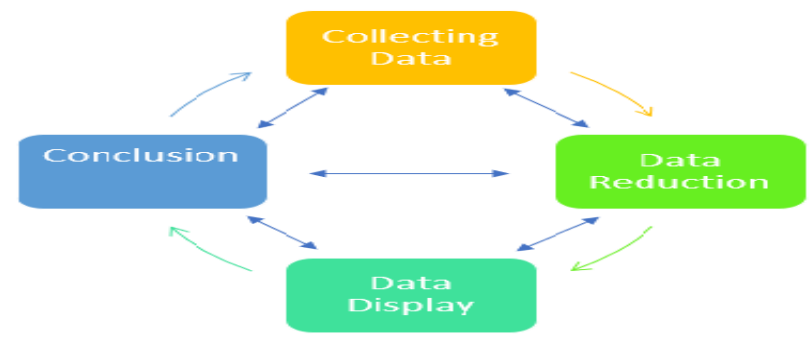

Gambar 1. Model Analisa Interaktif

\section{HASIL DAN PEMBAHASAN}

HASIL

Penelitian dilakukan melalui empat tahapan, diantaranya; a) Pengumpulan data; b) Reduksi Data; c) Menampilkan Data Hasil Reduksi (Data Display); dan d) Kesimpulan. Secara keseluruhan hasil penelitian ditampilkan dalam bentuk display sebagai berikut: 


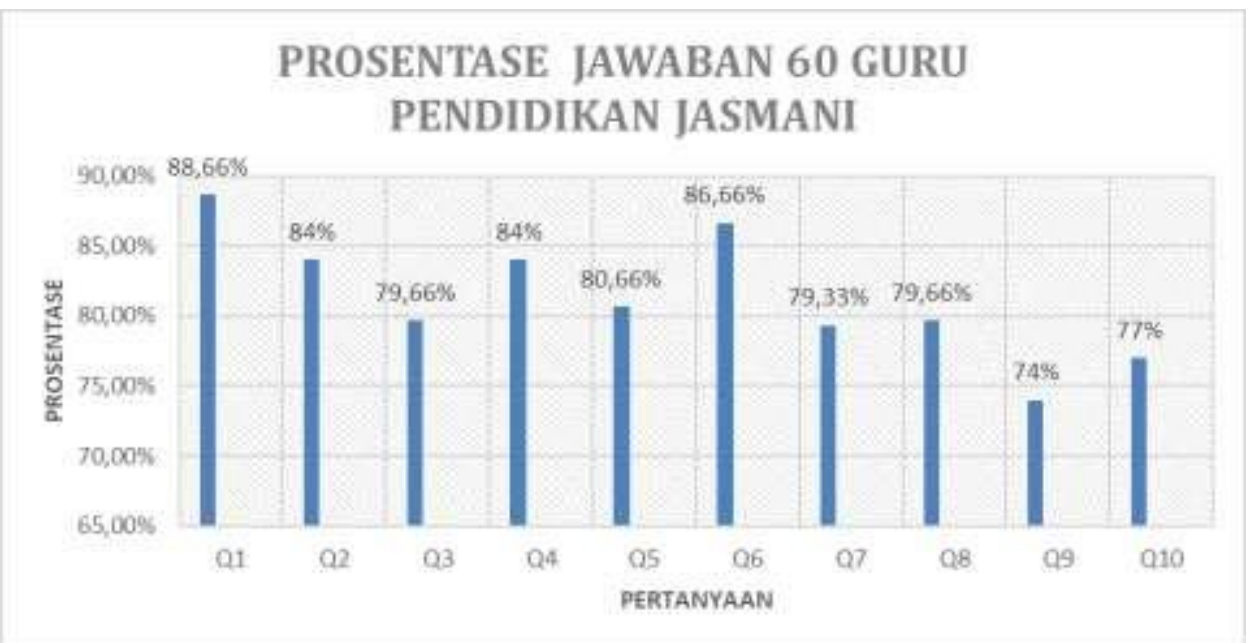

Gambar 2. Chart Prosentase Respon Guru Pendidikan Jasmani

Adapun daftar pertanyaan yang diberikan adalah sebagai berikut:

Tabel 1. Daftar Pertanyaan

\begin{tabular}{l} 
Pertanyaan \\
\hline Saya membawa perangkat seluler yang terhubung ke internet ke manapun \\
saya pergi \\
Saya kompeten dalam menggunakan email. \\
Saya kompeten dalam menggunakan Microsoft office, untuk presentasi \\
atau membuat beberapa sumber belajar \\
Saya dapat mengunduh file dari internet dan mengupload file ke email, g- \\
drive, g-kelas, dll. \\
Saya kompeten dalam menggunakan presentasi seperti PowerPoint, \\
bagikan layar pada pertemuan virtual platform seperti zoom, googlemeet, \\
dll. \\
Saya bisa menggunakan media sosial(Facebook,Twitter,Instagram, atau \\
whatsapps) untuk menyampaikan informasi dengan murid-murid saya. \\
Saya familiar dengan sistem manajemen pembelajaran (DepEd \\
Commons/Learning Resource Portal/LMS) \\
Saya dapat merancang kuis online dan menggunakan mereka dalam \\
mengajar kelas-kelas saya. \\
Saya bisa menggunakan diskusi online dan mengajar kelas saya \\
Saya dapat mengembangkan kegiatan pembelajaran elektronik yang \\
mendorong siswa saya untuk berpikir kritis
\end{tabular}

Pada tahapan pengumpulan data, diperoleh data dari subjek penelitian yaitu guru pendidikan jasmani sekolah dasar yang tersebar di seluruh 
kabupaten/kota di Jawa Tengah dengan keterangan sebagai berikut:

Tabel 2. Informasi Umum Responden

\begin{tabular}{|c|c|c|c|}
\hline $\begin{array}{l}\text { Jumlah } \\
\text { Respon } \\
\text { den }\end{array}$ & $\begin{array}{l}\text { Prosentase } \\
\text { Status } \\
\text { Kepegawaian }\end{array}$ & $\begin{array}{l}\text { Prosentase } \\
\text { Pengalaman Mengajar }\end{array}$ & Usia \\
\hline $\begin{array}{l}60 \\
\text { Orang }\end{array}$ & $\begin{array}{l}\text { Honorer : } 43.3 \% \\
\text { PNS: } 51.7 \% \\
\text { Lainnya: } 5 \%\end{array}$ & $\begin{array}{ll}5 & \text { Tahun: } 10 \% \\
<5 & \text { Tahun: } 40 \% \\
>5 & \text { Tahun: } 50 \%\end{array}$ & $\begin{array}{l}<30 \text { Tahun: } 37 \\
\text { orang (22,2\%) } \\
>30 \text { Tahun: } 23 \\
\text { orang } 13,8 \%)\end{array}$ \\
\hline
\end{tabular}

Pengumpulan data berikutnya adalah mengenai respon terhadap pertanyaan yang telah disebarkan melalui Googleform kepada 60 Pendidikan Jasmani. Berdasarkan hasil pengisian kuesioner oleh para guru pendidikan jasmani dengan hasil seperti pada tabel sebelumnya, maka langkah berikutnya adalah melakukan reduksi data dan menampilkan dalam bentuk prosentase sehingga hasil keseluruhan dapat diinterpretas ikan kedalam kategori sangat tidak siap, tidak siap, ragu, siap, bahkan sangat siap.

Tabel 3. Hasil Interpretasi Kesiapan Teknis Guru Pendidikan Jasmani (N=60)

\begin{tabular}{|c|c|c|c|c|c|c|}
\hline \multirow[t]{2}{*}{ Pertanyaan } & \multicolumn{5}{|c|}{ Skala Penilaian } & \multirow[t]{2}{*}{ Interpre tasi } \\
\hline & STS & TS & $\mathrm{N}$ & $\mathrm{S}$ & SS & \\
\hline $\begin{array}{l}\text { Saya membawa perangkat seluler } \\
\text { vang terhubung ke internet ke }\end{array}$ & 1 & - & 1 & 28 & 30 & \multirow{4}{*}{$\begin{array}{l}88,66 \% \\
\text { (Sangat Siap) } \\
84 \% \\
\text { (Sangat Siap) } \\
79,66 \% \\
\text { (Siap) } \\
84 \% \\
\text { (Sangat Siap) }\end{array}$} \\
\hline manapun saya pergi & 1 & 1 & 6 & 29 & 23 & \\
\hline $\begin{array}{l}\text { Saya kompeten dalam } \\
\text { menggunakan email. }\end{array}$ & 1 & 3 & 11 & 26 & 19 & \\
\hline $\begin{array}{l}\text { Saya kompeten dalam } \\
\text { menggunakan Microsoft office, } \\
\text { untuk presentasi ataum em buat } \\
\text { beberapa sumber belajar }\end{array}$ & - & 2 & 8 & 26 & 24 & \\
\hline $\begin{array}{l}\text { Saya dapat mengunduh file dari } \\
\text { internet dan mengupload f ile ke }\end{array}$ & - & 3 & 13 & 23 & 21 & $\begin{array}{l}80,66 \% \\
\text { (Sangat Siap) }\end{array}$ \\
\hline email, g-drive, g-kelas, dll. & 1 & 1 & 3 & 27 & 28 & $\begin{array}{l}86,66 \% \\
\text { (Sangat Siap) }\end{array}$ \\
\hline $\begin{array}{l}\text { Saya kompeten dalam } \\
\text { menggunakan presentasi seperti } \\
\text { PowerPoint, bagikan layar pada } \\
\text { pertemuan virtual platform } \\
\text { sepertizoom google }\end{array}$ & - & 8 & 24 & 20 & 8 & $\begin{array}{l}79,33 \% \\
\text { (Siap) }\end{array}$ \\
\hline meet, dll. & 1 & 5 & 12 & 28 & 14 & \multirow{3}{*}{$\begin{array}{l}79,66 \% \\
\text { (Siap) } \\
74 \% \\
\text { (Siap) } \\
77 \% \\
\text { (Siap) }\end{array}$} \\
\hline $\begin{array}{l}\text { Saya bisa menggunakan media } \\
\text { sosial(Facebook,Twitter, }\end{array}$ & 1 & 6 & 14 & 28 & 11 & \\
\hline $\begin{array}{l}\text { Instagram, atau whatsapps) untuk } \\
\text { menyampaikan }\end{array}$ & - & 3 & 15 & 30 & 12 & \\
\hline
\end{tabular}


Berdasarkan hasil reduksi dan pengolahan data merubah dari total skor yang diperoleh dari masing masing pertanyaan kedalam bentuk prosentase untuk memunculkan interpretasi, maka diperoleh hasil seperti pada tabel diatas, dengan rata rata berdasarkan hasil prosentase muncul interpretasi siap dan sangat siap. Langkah berikutnya dalam penelitian ini ada lah menampilkan data hasil penelitian yang akan ditampilkan atau dijelaskan pada tahap Display Data

Berdasarkan display data pada Gambar 2. diatas dapat diketahui bahwa Q1 (Pertanyaan 1) dengan hasil 88,66\% maka masuk dalam interpretasi "sangat siap"; Q2 dengan hasil 84\% masuk dalam interpretasi "sangat siap"; Q3 dengan hasil 79,66\% masuk dalam interpretasi "siap"; Q4 dengan hasil 84\% masuk dalam interpretasi "sangat siap"; Q5 dengan hasil 80,66\% masuk dalam interpretasi "sangat siap"; Q6 dengan hasil 86,66\% masuk dalam interpretasi "sangat baik"; Q7 dengan hasil 79,33\% masuk dalam interpretasi "siap"; Q8 dengan hasil 79,66\% masuk da lam interpretasi “siap"; Q9 dengan hasil 74\% masuk dalam interpretasi "siap"; dan Q10 dengan hasil 77\% masuk dalam interpretasi "siap".

\section{PEMBAHASAN}

Penelitian terdahulu mengenai hal hal yang berkaitan dengan kesiapan pelaksanaan pendidikan di Indonesia dalam situasi pandemi telah banyak dilakukan, salah satunya penelitian tentang "Kesiapan Pendidikan Indonesia Lakukan Pembelajaran Jarak Jauh dalam Situasi Pandemi COVID-19”, da lam hasil analisa penelitian tersebut dijelaskan bahwa Indonesia telah mempersiapkan infrastruktur virtual dengan baik, namun faktor guru dan sekolah masih perlu lebih memahami esensi pembelajaran jarak jauh. Guru cenderung gagap tentang teknologi, dari sini perlu dilihat seberapa siap siap guru dalam menghadapi tantangan pendidikan online dalam situasi pandemi (Churiyah, Sholikhan, Filianti, \& Sakdiyyah, 2020).

Hasil penelitian terdahulu lainnya salah satunya tentang "Kesiapan Guru untuk Pendidikan Jarak Jauh: Dari Teori ke Praktek" menghasilkan sebuah pernyataan bahwa sebagian besar responden (Guru Sekolah Menengah Atas) kurang memiliki pengetahuan teoritis dan keterampilan praktis untuk 
pelaksanaan pembelajaran jarak jauh dan kebanyakan dari mereka mengalami kesulitan dalam mengajar selama karantina (Nenko, 2020). Temuan lain mengatakan bahwa pendidikan online mampu memberikan efek yang sama efektifnya dengan pembelajaran tatap muka, tetapi masih banyak pertanyaan muncul tentang keberhasilan implementasinya di lingkungan pembelajaran online. Sehingga ada beberapa aspek yang perlu dipertimbangkan untuk pendidikan online di masa depan, salah satunya adalah tentang kesiapan dari guru pendidikan jasmani itu sendiri (Kwon, 2020)

Melihat hasil diatas, maka penelitian ini membuktikan bahwa pernyataan dalam penelitian terdahulu yang menyatakan bahwa Guru cenderung gagap teknologi, perlu dilihat seberapa siap guru dalam menghadapi tantangan pendidikan online dalam situasi pandemi (Churiyah et al., 2020) tidak sepenuhnya benar $100 \%$, karena terlihat kesiapan secara teknis dari para guru pendidikan jasmani di Sekolah Dasar di Jawa Tengah ada pada kategori siap, meskipun memang dalam beberapa komponen perlu dilakukan pelatihan secara mendalam dalam penggunaan dan pemanfaatan teknologi.

Selain itu, hasil penelitian kali ini juga membuktikan bahwa ternyata guru pendidikan jasmani di tingkat sekolah dasar di Jawa Tengah memiliki tingkat rata rata kesiapan yang baik dalam hal teknis untuk menghadapi pembe lajaran online, bertolak belakang dengan hasil penelitian yang berfokus pada guru sekolah me nengah atas dengan pernyataan yang menjelaskan bahwa sebagian besar mereka kurang memiliki pengetahuan teoritis dan keterampilan praktis untuk pelaksanaan pembelajaran jarak jauh (Nenko, 2020).

Sebagai penutup dalam pembahasan hasil penelitian ini, perlu menjadi informasi bagi para peneliti diluar sana terlebih para praktisi pendidikan jasmani, bahwa perlu dilakukan penelitian lebih lanjut mengenai kesiapan para guru pendidikan jasmani secara umum baik teknis dan juga pedagogis, sehingga nantinya mampu menjawab pertanyaan dari penelitian sebelumnya yaitu tentang Thinking about Hybrid or Online Learning in Physical Education? Start Here! (Daum, 2020), dengan pernyataan bahwa merancang program online atau hybrid itu sulit dan sangat memakan waktu. Guru perlu mempertimbangkan kerumitan merancang dan memelihara pembelajaran 
berkualitas tinggi di lingkungan online. Sehingga harapannya penelitian berikutnya mampu memberikan jawaban apakah kesiapan guru dalam menghadapi pembelajaran online ini dapat dijadikan sebagai tolok ukur bahwa pendidikan jasmani siap untuk sepenuhnya dilakukan secara hybrid atau online.

\section{SIMPULAN}

Berdasarkan hasil penelitian dapat disimpulkan bahwa kesiapan secara teknis para guru pendidikan jasmani dalam menghadapi tantangan pembe lajaran online sebagai akibat dari COVID-19 pada jenjang sekolah dasar berada pada interpretasi sangat siap. Hal lain yang perlu menjadi perhatian adalah dari hasil penelitian ini dapat memberikan informasi kepada para guru pendidikan jasmani dalam mempersiapkan diri secara teknis untuk menghadapi pembe lajaran pendidikan jasmani secara online. Serangkaian kegiatan yang telah dilakukan pada penelitian ini, menjadikan peneliti dapat memberikan saran bagi para insan akdemis untuk dapat memberikan upaya mempertahankan dan bahkan meningkatkan kesiapan para guru pendidikan jasmani sekolah dasar dalam menghadapi pembelajaran online, salah satunya dengan memberikan pelatihan, dan atau kursus peengembangan keterampilan yang terkait tentang penggunaan dan pemanfaatan teknologi untuk masa yang akan datang.

\section{DAFTAR PUSTAKA}

Ayuni, D., Marini, T., Fauziddin, M., \& Pahrul, Y. (2020). Kesiapan Guru TK Menghadapi Pembelajaran Daring Masa Pandemi Covid-19. Jurnal Obsesi: Jurnal Pendidikan Anak Usia Dini, 5(1), 414421.https://doi.org/10.31004/obsesi.v5i1.579

Azra, M. H. (2021). Efektivitas pembelajaran secara daring selama pandemi Covid-19 mata pelajaran Pendidikan Jasmani Olahraga Dan Kesehatan (PJOK) pada siswa SMK Negeri 1 Makassar. Doctoral Disertation Universitas Negeri Makassar.

Bayu, W. I., Waluyo, W., \& Victorian, A. R. (2020). Survei Pelaksanaan Pembelajaran Pendidikan Jasmani Dan Olahraga Se lama Pandemi Covid19. Bravo's : Jurnal Program Studi Pendidikan Jasmani Dan Kesehatan, 8 (4), 161-167.https://doi. org/10.32682/bravos.v8i4.1748 
Beard, J., \& Konukman, F. (2020). Teaching Online Physical Education: The Art of Connection in the Digital Classroom. Journal of Physical Education, Recreation and Dance, 91(7), 49-51. https://doi.org/10.1080/07303084.2020.1785772

Churiyah, M., Sholikhan, S., Filianti, F., \& Sakdiyyah, D. A. (2020). Indonesia Education Readiness Conducting Distance Learning in Covid-19 Pandemic Situation. International Journal of Multicultural and Multireligious $\quad$ Understanding, 7(6), 491-507. https://oi.org/10.18415/ijmmu.v7i6.1833

Darling-Hammond, L., \& Hyler, M. E. (2020). Preparing educators for the time of COVID ... and beyond. European Journal of Teacher Education, 43(4), 457-465. https://doi.org/10.1080/02619768.2020.1816961

Daum, D. N. (2020). Thinking about Hybrid or Online Learning in Physical Education? Start Here!: Editor: Brian Mosier. Journal of Physical Education, Recreation and Dance, 91(1), 42-44. https://doi.org/10.1080/07303084.2020.1683387

Filiz, B., \& Konukman, F. (2020). Teaching Strategies for Physical Education during the Covid-19 Pandemic: Editor: Ferman Konukman. Journal of Physical Education, Recreation and Dance, 91(9), 48-50. https://doi.org/10.1080/07303084.2020.1816099

Handarini, O. I., \& Wulandari, S. S. (2020). Pembelajaran Daring Sebagai Upaya Study From Home (SFH) Selama Pandemi Covid 19. Jurnal Pendidikan Administrasi Perkantoran (JPAP), 8(3), 496-503.

Hayati, N. (2020). Metode Pembelajaran Darin/E-Learning yang Efektif. Jurusan Ilmu Pendidikan Psikologi dan Bimbingan, 4.

Impact of Coronavirus Pandemic on Education. (2020). Journal of Education and Practice, 11(13), 108-121.https://doi.org/10.7176/jep/11-13-12

Kwon, E. H. (2020). Review of online learning in physical education teacher education (PETE) program. Journal of Physical Education and Sport, 20(6), 3560-3568. https://doi. org/10.7752/jpes.2020.06480

Lapada, A. A., Miguel, F. F., Robledo, D. A. R., \& Alam, Z. F. (2020). Teachers' Covid-19 Awareness, Distance Learning Education Experiences and Perceptions towards Institutional Readiness and Challenges. International Journal of Learning, Teaching and Educational Research,19(6), 127-144. https://doi.org/10.26803/ijlter.19.6.8

Moorhouse, B. L. (2020). Adaptations to a face-to-face initial teacher education course 'forced' online due to the COVID-19 pandemic. Journal of Education for Teaching, 46(4), 609-611. 
176 Wahyu Ragil Kurniawan ${ }^{1)}$, Ipang Setiawan ${ }^{2)}$, Dwi Gansar Santi ${ }^{3)}$ Wijayanti $^{3}$, Fatkhur Roż ${ }^{4)}$, Fani Alfriani ${ }^{5}$.Jp.jok (Jurnal Pendidikan. Jasmani, Olahraga dan Kesehatan). 5(1) 165-176

https://doi.org/10.1080/02607476.2020.1755205

Nenko, Y., Kybalna, N., \& Snisarenko, Y. (2020). The COVID-19 distance learning: insight from Ukrainian students. Revista Brasileira de Educação do Campo, 5, e8925-e8925.

Panol, R. F., Caballes, D. G., \& Vasquez, A. G. (2021). Teachers 'Readiness Level on Online Teaching : Embracing Distance Learning Modality.

Putria, H., Maula, L. H., \& Uswatun, D. A. (2020). Analisis proses pembelajaran dalam jaringan (daring) masa pandemi covid-19 pada guru sekolah dasar. Jurnal Basicedu, 4(4), 861-870. https://doi.org/10.31004/basicedu.v4i4.460

Rahman, T., Prasetyo, D. A., \& Mashuri, H. (2021). The Impact Of Online Learning During The Covid-19 Pandemic on Physical Education Teachers. Halaman Olahraga Nusantara (Jurnal Ilmu Keolahragaan), 4(2), 294-304 https://doi.org/10.31851/hon.v4i2.5638

Sadikin, A., \& Hamidah, A. (2020). Pembelajaran Daring di Tengah Wabah Covid-19. BIODIK. 6(2), 214-224. https://doi.org/10.22437/bio.v6i2.9759

Satrianingrum, A. P., \& Prasetyo, I. (2020). Persepsi Guru Dampak Pandemi Covid-19 terhadap Pelaksanaan Pembelajaran Daring di PAUD. Jurnal Obsesi: Jurnal Pendidikan Anak Usia Dini. 5(1), 633-640. https://doi.org/10.31004/obsesi.v5i1.574 